Rifkin has been pilloried for in the past. "Like all powerful tools, genetic information can be misused and abused. Discrimination based on genotype must be prohibited as a matter of basic civil rights," Healy told the legislators. Now is the right time to be studying and anticipating such problems, she said. "We don't want to have the genome in front of us and then scratch our heads about what this all means."

"The idea that there will be a huge databank of genetic information on millions of people is repulsive," Watson added. He pointed out that funding for research on the ethical, social and legal issues of the genome project have increased every year, from three per cent in 1990 to an estimated five per cent in 1992. "Five years from now, we may be spending ten per cent," he said.

This is heady stuff for Rifkin. "For Healy to sit there and say we've got problems with eugenics and genetic discrimination, I almost feel like I'm being left behind," he marvels. "All these people we've been fighting for the last 15 years had refused to accept the framework [of ethical and social concerns]. Now they talk of nothing else. We've got the molecular biologists accepting that you can't talk about the human potential without talking about eugenics."

Rifkin is not, however, about to pack up and go away. There are still plenty of genetic issues on which he differs from much of the scientific community, including animal patenting and the release of genetically engineered organisms (see below). And even on genetic privacy, Rifkin is not planning to rest on philosophical support from science's movers and shakers - he wants active lobbying.

"If Congress does not pass legislation, we will aggressively oppose the human genome project," he says. "We can make a hell of a stink. I believe that there are enough scientists out there to support us. I'm not naive - they're not going to man the barricades. But as of [last week's hearing] there is a new situation."

Perhaps. But 15 years of bad blood takes a while to get over. Anderson recalls how he gave Rifkin a list of researchers to contact for support on the genetic privacy issue. "Most people wouldn't even talk to him," he says. "Rifkin still feels so strongly on some issues. If someone comes up with a germline gene therapy [manipulating genes in reproductive cells], he'll file a lawsuit as fast as his fingers can fly over the word-processor keys."

Indeed, lawsuits are no way to make friends. But Rifkin believes that researchers need people like him. "When you're on the cutting edge of science", he says, "you don't stop to be reflective. You need pressure from the outside." With a little congressional prodding, genome researchers, at least, seem to agree.

Christopher Anderson

\section{Privacy bill vetoed}

CALIFornia governor Pete Wilson last week vetoed what would have been the first US law protecting the privacy of genetic information. Although the bill, which was drafted by Paul Billings, a geneticist at the California Pacific Medical Center, had passed both houses of the state legislature, Wilson argued that the issues surrounding genetic information needed more airing. "Since this field [of genetic diagnosis] is so new and so rapidly expanding", he wrote in a 14 October letter to legislators, "I am concerned that we are providing a remedy for a problem whose nature and magnitude are not yet sufficiently defined." The bill would have placed an eight-year ban on the use of genetic information in insurance and employment decisions (see Nature 353; 5 September 1991).

C.A.

\section{OSI confirms mix-up}

AN independent test by the US National Institutes of Health Office of Scientific Integrity (OSI) has confirmed that the AIDS blood test developed by researcher Robert Gallo was based on a French virus sent to him by the Paris-based Pasteur Institute. This appears to confirm what both Gallo and Pasteur researcher Luc Montagnier have already determined through genetic analysis of their own viral samples from the 1984 period in which the AIDS virus was first isolated. As part of its continuing investigation of Gallo's laboratory, OSI in July asked Roche Diagnostics Research to conduct an independent analysis of the samples. According to a terse OSI statement released last week, Roche's DNA sequencing studies showed "no evidence that the French [AIDS virus] isolate was misappropriated by Dr. Gallo or his staff in preparing the materials for the blood test."

Further, the Roche study confirmed what is now widely known-that a virus from the French patient LAI contaminated cultures in laboratories in France, England, and the United States.

Finally, OSI points out that it "has determined and announced previously that since Dr. Gallo had several HIV isolates in his laboratory, as well as a continuous culture of a virus not related to the French virus, he had no need to appropriate the virus from the Pasteur Institute." The Chicago Tribune, in an article this week, quotes former OSI deputy director Suzanne Hadley as calling that statement "completely erroneous". "We never made such an announcement," she is quoted as saying. But in a 5 October, 1990 statement, then-acting NIH director William Raub announced that OSI "has concluded that Dr. Gallo had a substantial number of HIV detections and isolations from several different sources at the critical time that [the French virus] was being grown..." C.A.

\section{PETA wins one}

PEOPLE for the Ethical Treatment of Animals (PETA) last week won a retraction from a magazine that had published an article alleging that the US animal-rights group was financially corrupt and that its best-known publicity photos were staged (see Nature 343, 580; 1990). As part of an out-of-court settlement, Washingtonian magazine agreed to print in its next issue a lengthy "correction and clarification" that withdraws most of the more damning allegation in a critical 1990 article by freelance journalist Katie McCabe. Among the allegations that McCabe retracts is that PETA co-founder Alex Pacheco had tied one of the 'Silver Spring Monkeys' in an unfamiliar experimental apparatus to take a picture that has since become one of the symbols of the animal-rights movement. The monkey was placed in the apparatus by laboratory personnel as part of a scheduled experiment, McCabe concedes. Washingtonian also retracts allegations that PETA had engaged in secret accounting procedures to channel funds to other animal-rights groups and activists; the allegations were based solely on interviews with former PETA employees who had been dismissed, one of whom subsequently retracted his statements after PETA sued him.

C.A.

\section{First to market}

\section{Sydney}

Australia is the first country to allow the sale of a genetically altered living organism for general commercial use. An Australian company, Biocare Technology Pty Ltd, is now marketing a pesticide that consists of a slightly altered version of a natural biological counter to the plant disease Crown Gall.

The pesticide has been used in one Australian state for three years under the name Nogall. But Allen Kerr of the University of Adelaide, who led the team that discovered Nogall, said that this was the first time that a genetically altered organism had been approved by any country for unrestricted national sale.

Kerr's team discovered the original Nogall organism, a strain known as $\mathbf{K}-\mathbf{8 4}$, during a lengthy search for a biological control for Crown Gall. Trials showed that after a period of exposure to Crown Gall, K-84 lost its effectiveness because it transferred a plasmid to the virus. The plasmid DNA allowed the virus to generate an antibody against the attacking K-84. That problem was overcome by altering the genes of K-84 to prevent the transfer.

The state of New South Wales approved the pesticide in 1988, but the Federal Government only granted registration last month. Biocare Technology has applied to register Nogall in the United States and Japan. 